\title{
RESPON K.H. AHMAD DAHLAN TERHADAP GERAKAN KRISTENISASI DI INDONESIA
}

\author{
LUKMAN MA'SA \\ lukman@stidnatsir.ac.id
}

Sekolah Tinggi Ilmu Da'wah Mohammad Natsir, Indonesia

\begin{abstract}
ABSTRAK
Tujuan Penelitian: Penelitian ini bertujuan untuk mengetahui respon KH. Ahmad Dahlan terhadap Gerakan Kristenisasi di Indonesia. Metode Penelitian: Kualitatif. Hasil Penelitian: Gerakan kristenisasi di Indonesia sudah ada sejak zaman penjajahan Belanda, para misionaris Kristen itu hadir sebagai sekutu Belanda yang ingin terus melanggengkan kekuasaannya di tanah air. Dimana salah satu cara untuk mengeksiskan penjajahannya di Indonesia adalah dengan mengkristenkan masyarakat Muslim Indonesia. Tentu saja gerakan kristenisasi ini mendapat penentangan dan perlawanan dari para ulama, tokoh dan masyarakat Muslim yang terusik aqidah dan keyakinannya. Tulisan ini mencoba mengkaji dan memaparkan respon salah satu tokoh Islam terkemuka Indonesia, yaitu K.H. Ahmad Dahlan dalam menghadapi gerakan kristenisasi ini. Hasil dari tulisan ini membuktikan bahwa K.H Ahmad Dahlan berhasil membendung gerakan kristenisasi dengan membentengi aqidah umat dan membuktikan kekeliruan ajaran agama Kristen. Meskipun pendekatan yang beliau gunakan lunak dan moderat tapi beliau sangat tegas dan gigih dalam menghadapi gerakan kristenisasi tersebut.
\end{abstract}

Kata Kunci: Kristenisasi, Muhammadiyah, Ahmad Dahlan, Dakwah

\section{PENDAHULUAN}

Tidak bisa dinafikan bahwa umat Islam Indonesia sedang menghadapi serangan aqidah yang luar biasa. Selain serangan sekularisasi, pluralisme dan liberalisasi, bahaya besar lainnya yang senantiasa mengintai umat Islam Indonesia adalah "Kristenisasi”. Sejak ratusan tahun lalu, para misionaris Kristen telah memasuki Indonesia untuk mengabarkan Injil, dan sejak itu pula, berbagai macam upaya dan strategi mereka canangkan untuk menjadikan Indonesia sebagai negri Kristen. Indonesia benarbenar mendapat prioritas utama sebagai lahan empuk injilisasi dunia. Insya Allah dalam paper singkat ini, penulis akan mencoba menguraikan bagaimana sikap dan respon $\mathrm{KH}$. Ahmad Dahlan terhadap gerakan Kristenisasi di Indonesia dimasa beliau hidup. Ini penulis anggap penting 
sebab bukan saja ingin belajar dari pendahulu kita, tapi juga ingin menegaskan bahwa KH. Ahmad Dahlan sangat tegas menolak gerakan Kristenisasi di Indonesia.

\section{Biografi Singkat KH. Ahmad Dahlan}

Kyai Haji Ahmad Dahlan (lahir di Yogyakarta, 1 Agustus 1868) adalah seorang Pahlawan Nasional Indonesia. Ia adalah putera keempat dari tujuh bersaudara dari keluarga K.H. Abu Bakar. KH Abu Bakar adalah seorang ulama dan khatib terkemuka di Masjid Besar Kasultanan Yogyakarta pada masa itu, dan ibu dari K.H. Ahmad Dahlan adalah puteri dari H. Ibrahim yang juga menjabat penghulu Kasultanan Yogyakarta pada masa itu.

Pada umur 15 tahun, beliau pergi haji dan tinggal di Mekah selama lima tahun. Pada periode ini, Ahmad Dahlan mulai berinteraksi dengan pemikiran-pemikiran pembaharu dalam Islam, seperti Muhammad Abduh $^{1}$, Al-Afghani, Rasyid Ridha ${ }^{2}$ dan Ibnu Taimiyah. Ketika pulang kembali ke kampungnya tahun 1888 , beliau berganti nama menjadi Ahmad Dahlan.

Pada tahun 1903, beliau kembali ke Mekah dengan membawa serta putranya Muhammad Siraj dan menetap selama 18 bulan. Pada masa ini, beliau sempat berguru kepada beberapa guru spesialis. Dalam ilmu Fiqih berguru kepada Kyai Makhfudz Termas dan lain-lain, Mufti Syafi'i dalam ilmu hadis, K. Asy'ari Baweyan dalam ilmu falak dan Syehk Ali Mishri Mekah dalam ilmu Qira'at. ${ }^{3}$ Dapat dipastikan pula bahwa beliau adalah murid Syeikh Ahmad Khatib yang juga guru dari pendiri NU, K.H.

${ }^{1}$ Interaksi Ahmad Dahlan denga pemikiran Muhammad Abduh dimulai dengan interaksi beliau dengan buku-buku karangan Muhammad Abnuh diantaranya : Kitab Tauhid, Tafsir juz Amma, Kitab Al Islam wan Nasroniyah, Tafsir al Manar, Kitab Syubhatunnashara wal Hudjdjatul Islam. Lihat Solichin Salam, Muhammadiyah dan Kebangunan Islam di Indonesia, Jakarta: Mega Djakarta, 1965. Hlm. 43-44

${ }^{2}$ Selama di Mekah KH. Ahmad Dahlan berkesempatan bertukar pikiran dengan Rasyid Ridha yang diperkenalkan KH Bakir, ide pembaruan meresap di hatinya yang mendorongnya melakukan perubahan-perubahan dalam kehidupan keagamaan kaum muslimin di Indonesia kemudian. Lihat A.Jainuri, Muhammadiyah Gerakan Reformasi Islam di Jawa Pada Awal Abad Kedua Puluh, Surabaya: Bina ilmu, 1981. Hlm. 27

${ }^{3}$ Kyai Syuja', Islam Berkemajuan Kisah Perjuangan K.H. Ahmad Dahlan dan Muhammadiyah Masa Awal, Ciputat: Al Wasath, 2009. Hlm. 53 
Hasyim Asyari. ${ }^{4}$ Pada tahun 1912, ia mendirikan Muhammadiyah di kampung Kauman, Yogyakarta.

Sepulang dari Mekkah, ia menikah dengan Siti Walidah, sepupunya sendiri, anak Kyai Penghulu Haji Fadhil, yang kelak dikenal dengan Nyai Ahmad Dahlan, seorang Pahlawan Nasional dan pendiri Aisyiyah. Dari perkawinannya dengan Siti Walidah, KH. Ahmad Dahlan mendapat enam orang anak. ${ }^{5}$ Disamping itu KH. Ahmad Dahlan pernah pula menikahi Nyai Abdullah, janda H. Abdullah. la juga pernah menikahi Nyai Rum, adik Kyai Munawwir Krapyak. KH. Ahmad Dahlan juga mempunyai putera dari perkawinannya dengan Ibu Nyai Aisyah (adik Adjengan Penghulu) Cianjur yang bernama Dandanah. Ia pernah pula menikah dengan Nyai Yasin Pakualaman Yogyakarta (Yunus Salam, 1968: 9). Beliau wafat di Yogyakarta, 23 Februari 1923 pada umur 54 tahun, dan dimakamkan di Karang Kajen, Yogyakarta. ${ }^{6}$

\section{Sejarah Singkat Gerakan Kristenisasi di Indonesia}

Berdasarkan kutipan Alwi Shihab dari buku Church History in Indonesia, Muller Kruger menyatakan bahwa, menurut sumber-sumber Arab kuno, pada pertengahan abad ketujuh sebuah komunitas Kristen hidup di Sibolga, Sumatra dan membangun gereja. Namun demikian pada periode awal ini agama Kristen belum mengalami perkembangan yang signifikan. $^{?}$

Hasil gerakan kristenisasi mulai nampak sejak kaum penjajah portugis datang ke Nusantara tepatnya di Maluku pada tahun 1512. Yang kemudian diikuti oleh kedatangan Spanyol dari arah barat, meluaskan

4 Alwi Shihab, Membendung Arus Respon Gerakan Muhammadiyah Terhadap Penetrasi Misi Kristen di Indonesia, Jakarat: Mizan, 1998. Hlm. 109

${ }^{5}$ yaitu Djohanah (istri pertama Haji Hilal), Siradj Dahlan (Menjadi Direktur Madrasah Muallimin Muhammadiyah Yogyakarta, wafat 1948), Siti Busyro (Istri H. Isom Dja'far), Siti Aisyah (Istri Kedua H. Hilal, yang kemudian dikenal dengan Aisyah Hilal), Siti Zaharah (Istri H. Masykur Banjarmasin), Irfan DahlanA. Lihat Jainuri, Muhammadiyah Gerakan Reformasi Islam di Jawa Pada Awal Abad Kedua Puluh, hlm. 25. Yang juga mengutip bahwa Irfan Dahlan ini kemudian bergabung dalam gerakan Ahmadiyah Kadian (Lihat AK Pringgodigdo, Sejarah Pergerakan Rakyat Indonnesia, Jakarta: Dian Rakyat, 1977. Hlm. 95)

${ }^{6} \mathrm{http} / / /$ id.wikipedia.org/wiki/Ahmad_Dahlan\#cite_note-2/

7 Alwi Shihab, Membendung Arus Respon Gerakan Muhammadiyah Terhadap Penetrasi Misi Kristen di Indonesia, hlm. 31. Adapun paparan mendetail mengenai kedatangan awal agama Kristen di Indonesia, dapat dilihat dalam buku Theodor Muller Kruger, Sedjarah Gereja di Indonesia, Jakarta: Badan Penerbitan Kristen , 1959. 
jaringan perdagangan dan penyebaran agama Kristen ke daerah-daerah sekitarnya, bahkan hingga ke Jawa. ${ }^{8}$ Pada dasarnya tujuan utama dari penjajah tersebut adalah mengeruk keuntungan ekonomi, tetapi untuk memuluskan tujuan tersebut, mereka juga menggunakan agama Kristen sebagai alat imprealisme, yang kebetulan juga mempunyai misi menyebarkan agamanya dan dendam perang salib kepada umat Islam. Akhirnya, terjalinlah kerjasama dengan slogan "Gold, Glory, and Gospel" (Emas, Kejayaan, dan Injil).

Bahkan Dr. Jan S. Aritonang" dalam seminar "Kristenisasi dan Islamisasi" di Jakarta, 24 Juli 1999, mengungkapkan, bahwa Spanyol dan Portugis, ketika hendak menjajah dunia, mendapat restu dan mandat dari Paus Alexander VI tahun 1493 (dipertegas dalam perjanjian Tordesilas, 1494), ${ }^{10}$ yang pada pkokonya mengamanatkan agar para penjelajah dan pedagang dari dua negri beragama Kristen katolik itu menyiarkan iman katolik. ${ }^{11}$

Berbeda dengan Portugis dan Spanyol, Negara dan masyarakat Belanda belum pernah berjumpa secara fisik dengan umat dan penguasa Islam sebelum mereka datang ke Asia. Meski demikian di samping mengejar keuntungan ekonomis dan ikut membangun imperium Belanda, VOC juga mendapat mandat dari gereja Protestan yang berstatus sebagai gereja negara, untuk menyebarkan iman Kristen, sesuai dengan isi pasal 36 Pengakuan Iman Belanda tahun 1561. ${ }^{12}$

${ }^{8}$ Jan S. Aritonang, Sejarah Perjumpaan Kristen dan Islam di Indonesia, Jakarta : gunung Mulia, 2006. Hlm. 13-14

${ }^{9}$ Dr. Jan S. Aritonang adalah pendeta Gereja Kristen Protestan Indonesia (GKPI) sejak tahun 1977 dan dosen Sejarah Gereja di Sekolah Tinggi Teologi (STT) Jakarta.

${ }^{10}$ Perjanjian Tordesilas adalah suatu perjanjian yang dibuat oleh Kerajaan Katolik Portugis dan kerajaan katolik Spanyol. Dipinpin oleh Paus Alexander VI, 1492-1503. Dalam perjanjian ini Paus memberikan kewenangan kepada Portugis untuk mengusai dunia belahan timur. Sebaliknya kepada Spanyol diberikan kewenangan untuk menguasai dunia belahan barat. Lihat Ahmad Mansur Suryanegara, Api Sejarah, Bandung: Salamadani, 2009. Hlm. 157

11 Adian Husaini, Solusi Damai Islam Kristen di Indonesia, Jakarta: Pustaka Da'i, 2003. Hlm. 119

12 VOC ( Kongsi Dagang Hindia Timur), dibentuk atas usul parlemen Belanda tahun 1598, VOC dalam melakukan kegiatannya di Indonesia didasarkan pada laporan Frederick de Houtman yang telah melakukan penjajagan ke Nusantara sebanyak dua kali pada tahun 1596 dan 1599. Lihat S. Aritonang, Sejarah Perjumpaan Kristen dan Islam di Indonesia, hlm. 46-51 
Untuk menaklukkan dan mempertahankan kekuasaannya, pemerintah kolonial Belanda ketika itu -- atas nasehat Snouck Hurgronje -- membagi Islam kedalam tiga kategori: (1) bidang agama murni dan ibadah, (2) bidang sosial kemasyarakatan, (3) bidang politik. Resep Snouck Hurgronje inilah yang dikenal sebagai "Islam politiek" atau kebijakan pemerintah kolonial untuk menangani masalah Islam di Indonesia. Dari ketiga pembagian tersebut, pemerintah memberi keleluassan kepada umat Islam kecuali dalam bidang politik, semua usaha yang akan membawa rakyat kepada fanatisme dan Oan-Islam akan di cegah. ${ }^{13}$

Sementara dalam catatan Deliar Noer, mengungkapkan bahwa, sebagai orang-orang yang ingin terus berkuasa di kepulauan ini, maka bagi Belanda masalah yang pokok adalah bagaimana menimbulkan persaan senang penduduk Indonesia terhadap pemerintahan Belanda. Dalam hal ini terdapat dua pandangan : Pertama, unsur budaya, bagaimana mengembangkan kebudayaan Barat sehingga orang Indonesia menerima kebudayaan ini sebagai kebudayaan mereka walaupun tanpa mengesampingkan kebudayaan sendiri. Hal ini disebut "assosiasi" yang bermaksud untuk mengikat jajahan lebih erat padah penjajah dengan menyediakan bagi penduduk jajahan itu manfaat-manfaat yang terkandung dalam kebudayaan pihak penjajah dengan menghormati sepenuhnya kebudayaan lokal. Pandangan kedua, adalah "kristenisasi" bagaimana mengubah agama penduduk, yang Islam maupun yang bukan, menjadi Kristen. Menurut missi (Kristen sendiri ini akan lebih mudah ilakukan bila pandangan pertama terpenuhi, yang tentunya akan sangat menguntungkan pemerintah Belanda, sebab penduduk pribumi mengenal eratnya hubungan agama dengan pemerintahan. Setelah masuk Kristen akan menjadi warga-warga yang loyal lahir batin bagi kompeni. ${ }^{14}$

Meskipun fakta-fakta sejarah seperti diatas sangat jelas, tokohtokoh Kristen Indonesia - seperti Dr. W.B. Sidjabat dan TB Simatupang - biasanya berusaha mengelak bahwa kekuasaan kolonial Belanda ikut membantu penyebaran agama Kristen di Indonesia. Menurut mereka, kaum misionaris sama sekali tidak ada kaitannya dengan ambisi duniawi kaum kolonialis. Penyebaran agama Kristen, lebih disebabkan oleh kuasa Alkitab dan bukan terutama disebabkan oleh orang-orang Kristen. ${ }^{15}$

13 Adian Husaini, Wajah Peradaban Barat dari Hegemoni Kristen ke Dominasi Sekular-Liberal, Jakarta: Gema Insani Press, 2005. hlm. 197-198

${ }^{14}$ Delier Noer, Gerakan Moderen Islam di Indonesia 1900-1942, Jakarta:

LP3ES, Cet.8, 1996. hal. 26-27

${ }^{15}$ Adian Husaini, Majalah Media Dakwah, Edisi No. 375, Muharram 1428/Februari 2007. Hlm.8 
Setelah Indonesia Merdeka, Indonesia menjadi sasaran misi Kristen dari segenap penjuru dunia. Beragam media digunakan seperti film, kaset, buku-buku, kapal-kapal penginjil yang mengitari pantai-pantai dan kepulauan seperti Lombok, Sumbawa, Sulawesi dan Kalimantan. Di daerah luar Jawa seperti NT'T dan Kalimantan misi Kristen telah memiliki pemancar radio dan pesawat terbang cesna. Bahkan pada wilayah-wilayah tertentu, mereka mendirikan landasan pesawat khusus dengan izin dari Depertemen Perhubungan. ${ }^{16}$ Dalam bidang pemerintahan, politik, mereka senantiasa melakukan maneuver-manuver, mulai dari penolakan Piagam Jakarta, perjuangan di konstituante untuk menolak Islam sebagai dasar negara, gugatan terhadap SKB dua mentri mengenai penyiaran agama dan pendirian rumah ibadat, hingga penolakan UU Sisdiknas tahun 2003 yang mengharuskan sekolah menyediakan guru agama bagi siswa sesuai agamanya.

\section{HASIL DAN DISKUSI}

Salah satu teori yang berkembang tentang faktor-faktor lahirnya Muhammadiyah adalah perkembangan kegiatan misi Kristen di Jawa. Penetrasi Kristen ini berawal ketika para penguasa keraton Yogyakarta, atas desakan pemerintah kolonial Belanda, menyetujui pencabutan larangan penginjilan terhadap masyarakat Jawa. ${ }^{17}$ kegiatan kristenisasi yang lebih dalam lagi terjadi pada tahun 1850-an ke wilayah Jawa Tengah, yang menjadi dorongan kuat bagi lahirnya kesadaran kaum muslimin untuk melawan kegiatan-kegiatan misi ini.

Pada tahun-tahun pertama abad ke-20, masa awal "Politik Etis"18 sekolah-sekolah misi Kristen mulai ikut serta dalam program pendidikan pemerintah. Bagi kaum muslimin, ini adalah ancaman besar dari hasrat pemerintah kolonial untuk mengkristenkan masyarakat Jawa.

\footnotetext{
${ }^{16} \mathrm{http}: / /$ www.almanar.co.id/artikel-asatidzah/misi-kristen-diindonesia.html/

${ }^{17}$ Kekuasaan Sultan terlalu lemah untuk menentang kehendak pemerintah kolonial itu. Kesepakatan awal antara pemerintah kolonial dan sultan untuk mengizinkan beroperasinya misi-misi Kristen tidak lebih dari setahun, tetapi secara sewenang-wenang dilanggar oleh pemerintah Belanda. Alwi Shihab, Membendung Arus Respon Gerakan Muhammadiyah Terhadap Penetrasi Misi Kristen di Indonesia, hlm. 248

${ }^{18}$ Ketika "politik Etis" (dengan triloginya : Educatie (edukasi), Irigatie (Irigasi), dan Emigratie (emigrasi)).pertama kali diterapkan, pemerintah belanda didominasi oleh orang-orang Kristen yang sadar-diri, yang mendukung kristenisasi di Indonesia. Ibid. hlm. 248.
} 
Startegi ulama dalam menjawab tantangan tersebut adalah dengan membina kesadaran jiwa massa pendukungnya dan terumuskan dalam bahasa Jawa sederahana: mangan ora mangan asal kumpul. Artinya, makan atau tidak makan hendaknya tetap berjama'ah dengan ulama. Jangan sampai menyebrang berpihak kepada penjajah. Dengan kata lain, jangan sampai kelaparan dijadikan alasan untuk beralih agama dan mendukung penjajah. Ulama Sunda pun mengajarkan dengan bahasa: bongkok ngoroyok, bengkung ngariung. Walaupun secara pisik berkondisi sangat parah, jiwa tetap wajib istiqamah dan selalu berjama'ah, jangan sampai menjauh dari kepemimpinan ulama. ${ }^{19}$

Memasuki tahun 1912 M, Surakarta dan Yogyakarta dijadikan target pemerintah colonial Belanda untuk dipatahkan kekuatan Islamnya dan dijadikan medan kritenisasi. Alasannya, Surakarta dan Yogtyakarta telah dikelilingi pusat-pusat pendidikan kristenisasi dari Ungaran, Salatiga, boyolali, dan kebumen, serta Magelang sebagai pusat pendidikan serdadu Belanda.

Menghadapi tantangan demikian, K.H. Ahmad Dahlan dengan organisasinya giat melakukan tabligh, merapikan dan mempermodern caranya. K.H. Ahmad Dahlan, bahkan sering mengadakan diskusidiskusi dengan pastur dan pendeta. Tujuannya adalah untuk menunjukkan kebenaran Islam dan kemampuan umatnya dalam mempertahankan agamanya. ${ }^{20}$ K.H. Ahmad Dahlan berusaha menghindari konfrontasi langsung dengan misi Kristen. Dalam pandangannya, menantang dan melawan peran aktif mereka dan menghentikan penetrasinya melalui konfrontasi langsung adalah sesuatu yang tidak efektif dan strategis. Baginya, yang lebih penting dari itu adalah membangkitkan kesadaran kaum Muslim mengenai akibat-akibat yang akan muncul dari kegiatan misi tersebut. Oleh sebab itu, membangun infrastruktur gerakan lebih diutamakan daripada terlibat langsung dalam konfrontasi sengit dengan kelompok Kristen. Dengan berbuat demikian, Ahmad Dahlan bermaksud menjadikan kaum Muslim mampu menghadapi peningkatan pengaruh misi Kristen. Hal itu menyebabkan K.H. Ahmad Dahlan dan Muhammadiyah dibenci sebagian kalangan karena dianggap mendukung rezim colonial atau sekurang-kurangnya tidak menentangnya. ${ }^{21}$

${ }^{19}$ Ahmad Mansur Suryanegara, Api Sejarah, hlm. 308

${ }^{20}$ Afif Azhari dan Mimien Maimunah, Muhammad Abduh dan

Pengaruhnya di Indonesia, Surabaya: Al-Ikhlas, 1999, hlm. 101.

21 Boeah Congres Muhammadijah Seperampat Abad, Yogyakarta: Hoofdcomte, Congres Muhammadiyah, 1936, hlm. 33, dalam Alwi Shihab, 
Dengan dasar pertimbangan tersebut K.H. Ahmad Dahlan berhasil menjalin kontak dan persahabatan yang erat dengan banyak pendeta Kristen. Ketika mengundang orang-orang Kristen ke forum yang diselenggarakannya atau menerima undangan mereka, baik untuk mengadakan pembicaraan pribadi maupun mengikuti diskusi terbuka. Ini dilakukan Ahmad Dahlan bukan karena mentolerir misi kristenisasi yang mereka lakukan, namun lebih pada metode dalam menghadapi dan merespon misi penginjilan tersebut. Disebutkan beberapa kisah bagaimana Dahlan menda'wahkan Islam melalui metode debat. Ia penah menantang misionaris Kristen bernama Domine Baker dari Belanda, Dr. Zwemer, seorang misionaris Amerika yang ditunjuk menyebarkan Injil di kalangan bangsa Asia, termasuk Indonesia, demikian juga dengan misionaris lainnya Dr. Laberton. Dimana Ahmad Dahlan mampu mengungguli mereka dalam debat-debat yang dilakukan. ${ }^{22}$

Muhammadiyah dibawah kepemimpinan K.H. Ahmad Dahlan juga aktif menentang politik Kristenisasi yang dilaksanakan pemerintah Hindia Belanda. Usaha untuk menjalankan prinsip-prinsip Kristen dan pemerintahan, seperti "Surat Edaran Mingguan" dan "Surat Edaran Pasar" yang melarang segala kegiatan resmi pada hari Minggu, menimbulkan kegelisahan penduduk yang tidak mengenal nilai atau prinsip itu dalam lingkungan budayanya. Sudah barang tentu hal ini mendapat oposisi dari umat Islam yang dipelopori oleh organisasi Muhammadiyah. Organisasi ini kemudian melancarkan kontra-aksi yang berupa pendirian lembaga-lembaga sosial, seperti sekolah-sekolah, klinik, dan panti asuhan. ${ }^{23}$

Sebagaimana telah diketahui, pemerintah kolonial Belanda beserta lembaga zending dan misi pada masa politik etis membuka semakin banyak sekolah-sekolah Barat. Didirikannya sekolah-sekolah tersebut mengakibatkan perubahan yang besar dalam pendidikan agama di Pulau Jawa. Anak laki-laki dan wanita yang setiap hari berada di bangku sekolah tidak mempunyai waktu untuk pergi ke pesantren. Adat lama, bahwa seorang priyayi mengirimkan anak laki-lakinya ke pesantren, sekarang sudah tidak ada. Dalam beberapa kalangan masyarakat, pengiriman anakanak ke sekolah oleh orang tua menyebabkan pendidikan agama mereka terabaikan. Orang tua yang berasal dari lingkungan yang taat dan mengharapkan anak-anaknya juga mempunyai pengetahuan agama

Membendung Arus Respon Gerakan Muhammadiyah Terhadap Penetrasi Misi Kristen di Indonesia, hlm. 160

${ }^{22} \mathrm{Ibid}$, hlm. 161.

${ }^{23}$ Marwati Djoened Poesponegoro dan Nugroho Notosusanto, Sejarah Nasional Indonesia, Jilid V, hlm. 60

86|Jurnal Dakwah| Vol.1 No.2 |2018 
sekarang harus memilih satu di antara dua kemungkinan, yaitu mengirimkan anaknya ke sekolah swasta yang juga diberi pelajaran agama atau memberi pelajaran agama khusus di luar jam sekolah. Sekolahsekolah yang didirikan oleh Muhammadiyah menjadi solusi pilihan karena menggabungkan pendidikan agama dan pendidikan umum dengan menggunakan metode modern. ${ }^{24}$

Bagi Ahmad Dahlan dan Muhammadiyah, Kristenisasi bukan saja dianggap sebagai suatu tantangan, tetapi juga merupakan suatu contoh bagi para pemimpin Muslim. Cara-cara yang dipergunakan dalam kegiatan-kegiatan misi Kristen banyak dijadikan contoh. Pendirian sekolah-sekolah, rumah sakit, klinik, dan panti asuhan oleh Muhammadiyah banyak mengadopsi cara dari misi Kristen. Perawatan fakir miskin dan bantuan kepada orang-orang yang membutuhkan dan sebagainya, mungkin telah dilakukan secara tradisi, tetapi ini semata-mata terletak pada inisiatif perseorangan. Malah pengumpulan zakat pun bergantung semata-mata pada kesediaan orang-orang Islam sendiri. Anak-anak yatim pada umumnya mendapat tempat perlindungan pada keluarga berada. Sebuah keluarga Muslim secara tradisi ingin memelihara anak-anak yatim tersebut karena kepercayaan bahwa ini akan membawa berkah bagi mereka. Oleh sebab itu, pengaturan anak yatim dengan menyediakan rumah dan mengatur rumah khusus bagi mereka adalah suatu inovasi, demikian pula halnya dengan klinik kesehatan. ${ }^{25}$

Sebuah kegiatan lain misi Kristen yang dijadikan contoh oleh Muhammadiyah adalah gerakan kepanduan. Gerakan kepanduan Muhammadiyah, Hizbul Wathan, dibentuk pada 1918 oleh Ahmad Dahlan setelah memperoleh keterangan tentang persoalan kepanduan ini dari seorang guru Muhammadiyah yang mengajar di Solo. Guru ini melihat latihan-latihan kepanduan misi Kristen di alun-alun Mangkunegaran. Mengakui manfaat yang diberikan oleh gerakan seperti ini, Ahmad Dahlan tidak ragu-ragu untuk mengambil keputusan guna membentuk Hizbul Wathan. Di samping latihan kepanduan yang biasa, pandu-pandu Muhammadiyah itu diberikan juga pelajaran-pelajaran agama serta latihan dalam berorganisasi pada umumnya untuk mempersiapkan mereka pada tuntutan yang diperlukan apabila mereka dewasa nanti dan bergabung dengan organisasi Muhammadiyah. ${ }^{26}$

${ }^{24}$ G.F. Pijper, Fragmenta Islamica; Beberapa Studi Mengenai Sejarah Islam di Indonesia Awal Abad XX, Jakarta: UI Press, 1987, hlm. 21-22.

${ }^{25} \mathrm{http}: / /$ masyumicentre.com/mc/index.php/beranda/pembaca-menulis/234respons-muhammadiyah-terhadap-kristenisasi/ diakses tanggal 27 September 2012

${ }^{26}$ Deliar Noer, Gerakan Moderen Islam di Indonesia 1900-1942, hlm. 91- 
Pasca kepemimpinan Ahmad Dahlan, Muhammadiyah semakin agresip dan keras menentang kristenisasi, terutama dibawah kepemimpinan Fachruddin (1923-1929). Pada masa ini merupakan tahap paling dramatis jika dilihat dalam kerangka perjumpaan Muhammadiyah dengan misi Kristen. Sejak itu, Muhammadiyah menjadi lebih bersikap bermusuhan terhadap misi Kristen, yang dianggap tidak bersahabat dengan islam. Muhammadiyah semakin bersikap tegas dan militan dalam kritik terbukanya terhadap misi Kristen. ${ }^{27}$

\section{KESIMPULAN}

Berdasarkan pembahasan dan penelaahan dalam paper ini, bisa disimpulkan bahwa kehadiran misi Kristen dan penetrasi mereka di negri ini, menjadi salah satu faktor pendorong utama yang memicu munculnya semangat keagamaan K.H. Ahmad Dahlan yang menggebu-gebu, yang kemudian memprakarsai lahirnya Muhammadiyah sebagai respon terhadap misi Kristen tersebut.

K.H. Ahmad Dahlam dalam merespon gerakan kristenisasi di negri ini menggunakan pendekatan yang lunak dan moderat, dalam arti ia berusaha menghindari konfrontasi langsung dalam membendung gerakan mereka. Dan lebih mengutamakan untuk membekali dan membentengi kaum muslimin dari pemurtadan. Meski Ahmad Dahlan bersikap moderat dalam menghadapi Kristenisasi, bukan berarti beliau menyetujui atau tidak menentang gerakan tersebut, karena pada kenyataannya K.H. Ahmad Dahlan dalam membendung gerakan kristenisasi tersebut adalah melalui pembekalan dan membentangi kaum muslimin dari penetrasi Kristen yang dilakukan oleh para misionaris-misionaris yang memang ditugaskan di negri ini untuk memurtadkan kaum muslimin itu. Bahkan K.H. Ahmad Dahlan sering menantang debat para misionaris tersebut untuk menunjukan kebenaran Islam dan kekeliruan mereka. Kita juga dapat melihat generasi Muhammadiyah pasca Ahmad Dahlan yang begitu keras dalam menentang gerakan Kristenisasi tersebut.

Demikianlah respons K.H. Ahmad Dahlan dan tokoh-tokoh Muhammadiyah lainnya terhadap Kristenisasi pada masa politik etis. Hal ini menunjukkan betapa gigih dan konsisten para pendahulu kita memperjuangkan Islam. Sikap seperti itu sudah selayaknya dijadikan teladan oleh generasi selanjutnya. Mengingat Kristenisasi tetap menjadi salah satu tantangan da'wah terbesar bagi umat Islam di negeri ini, kita semestinya berusaha mewarisi semangat dan konsistensi mereka.

${ }^{27}$ Alwi Shihab, Membendung Arus Respon Gerakan Muhammadiyah Terhadap Penetrasi Misi Kristen di Indonesia, hlm. 162

$\mathbf{8 8 | J u r n a l}$ Dakwah | Vol.1 No.2 |2018 


\section{DAFTAR PUSTAKA}

A.Jainuri, Muhammadiyah Gerakan Reformasi Islam di Jawa Pada Awal Abad Kedua Puluh, Surabaya: Bina ilmu, 1981

Adian Husaini, Solusi Damai Islam Kristen di Indonesia, Jakarta: Pustaka Da’i, 2003

Adian Husaini, Wajab Peradaban Barat dari Hegemoni Kristen ke Dominasi Sekular-Liberal, Jakarta: Gema Insani Press, 2005

Afif Azhari dan Mimien Maimunah, Mubammad Abdub dan Pengarubnya di Indonesia, Surabaya: Al-Ikhlas, 1999

Ahmad Mansur Suryanegara, Api Sejarah, Bandung: Salamadani, 2009

AK Pringgodigdo, Sejarah Pergerakan Rakyat Indonnesia, Jakarta: Dian Rakyat, 1977

Alwi Shihab, Membendung Arus Respon Gerakan Mubammadiyah Terbadap Penetrasi Misi Kristen di Indonesia, Jakarat: Mizan, 1998

Delier Noer, Gerakan Moderen Islam di Indonesia 1900-1942, Jakarta: LP3ES, Cet.8, 1996

G.F. Pijper, Fragmenta Islamica; Beberapa Studi Mengenai Sejarah Islam di Indonesia Awal Abad XX, Jakarta: UI Press, 1987

Jan S. Aritonang, Sejarah Perjumpaan Kristen dan Islam di Indonesia, Jakarta : gunung Mulia, 2006

Kyai Syuja', Islam Berkemajuan Kisah Perjuangan K.H. Abmad Dablan dan Muhammadiyah Masa Awal, Ciputat: Al Wasath, 2009

Majalah Media Dakwah, Edisi No. 375, Muharram 1428/Februari 2007

Marwati Djoened Poesponegoro dan Nugroho Notosusanto, Sejarah Nasional Indonesia, Jilid V

Solichin Salam, Muhammadiyah dan Kebangunan Islam di Indonesia, Jakarta: Mega Djakarta, 1965

Theodor Muller Kruger, Sedjarah Gereja di Indonesia, Jakarta: Badan Penerbitan Kristen, 1959.

http://masyumicentre.com

http://www.almanar.co.id

http://id.wikipedia.org 